\title{
Formation of value attitude to the motherland in children of young school age
}

\author{
O.V. Kolesova ${ }^{1 *}, S . A$. Zaitseva $^{2}$, and N.N. Demeneva ${ }^{3}$ \\ ${ }^{1}$ Minin Nizhny Novgorod State Pedagogical University, Nizhny Novgorod, Russia \\ ${ }^{2}$ Minin Nizhny Novgorod State Pedagogical University, Nizhny Novgorod, Russia \\ ${ }^{3}$ Minin Nizhny Novgorod State Pedagogical University, Nizhny Novgorod, Russia
}

\begin{abstract}
The education system in modern society is aimed at ensuring the spiritual and moral development of an individualbasing on the formation of the value attitude towards the Motherland. The authors appeal to the theoretical foundations of the formation of the value attitude towards the Motherland in schoolchildren, and consider various approaches of Russian and foreign researchers. At present, the problem of the formation of the value attitude towards the Motherland in schoolchildren is connected with the formation and development of an individual as a highly moral and responsible citizen of the country. It is the younger school age that is favorable for the formation of the value attitude towards the Motherland, which contributes to the acquisition of moral experience, moral knowledge, and the introduction of the child to the values of the society. The results of the formative stage made it possible to draw a conclusion about the effectiveness of formative activities in the organization of experimental work.
\end{abstract}

\section{A problem statement}

The formation of the value attitude of primary school students to their Motherlandis one of the most difficult challenges at the present stage of the development of education. Dynamic changes in modern society require updating theoretical and practical approaches in the field of spiritual and moral education. At the same time, there is the need to create the foundation of morality for the younger generation. The historical experience of any country shows that the most important condition for the formation of a law abiding societyis the patriotic education of youth [1]. Today, the policy of any state is characterized by a focus on fostering patriotism and love for the Motherland. The concept of spiritual and moral development and upbringing of a citizen of Russia considers the possibilities of a school as the most important factor providing social and pedagogical support for the formation and development of a highly moral, responsible, proactive citizen of Russia [2]. That is why the educational system, based on the requirements of the society in the field of upbringing,

\footnotetext{
* Corresponding author: ipcs-profped@yandex.ru
} 
forms the value attitude of primary schoolchildren, develops a sense of pride of the country, loyalty to moral values and spiritual traditions.

Younger school age is sensitive for the development of stable cognitive needs and interests, including for the formation of value orientations. The process is characterized by the accumulation of knowledge about relationships between people, various aspects of society, freedom of choice. V.A. Mukhina believes that a junior schoolchild uses the acquired moral experience and moral knowledge as the basis for the value attitude towards the ideals of society [3]. The age of the child, the specificity of their moral development predetermines the peculiarities of the formation of the value attitude towards the Motherland, which includes the formation of ideas about the peoples of the country, famous people, traditions, values and culture of the Russian people, the main character traits: generosity, responsiveness, courage, kindness and hard work. Therefore, the most important direction of primary school is the task of forming the value orientations of students, helping the child to realize themselves in belonging to the community of citizens of their state. In order for the value attitude to the Motherland to become a personality trait, it must be comprehended more than once, and then constantly realized in the student's direct activity and behavior.

A theoretical analysis of the psychological and pedagogical literature has shown that there are many theories and approaches that provide for the development of the value attitude towards the Motherland. V.A. Sukhomlinsky [4], K. D. Ushinsky [5] reveal the importance of fostering love for the Motherland, family, home on the basis of the spiritual and moral formation of the individual. L.I. Bozovic, L.S. Vygotsky, P.P. Blonsky, R. Atkinson, focusing on the age of the primary school student, believe that it is at this age that an active process of accumulating knowledge about the positive and negative aspects of social life takes place. In the work of P. Ya. Halperin [6], the value attitude towards the Motherland is associated with a certain level of personality action, which sets specific goals and relies not only on personal experience of interacting with people, but also on social one.

The problem of forming a value attitude towards the Motherland is studied in the works of Russian and foreign educators. In connection with our research topic, the most relevant are the works that reveal the image of the Motherlandand its significance for a schoolchild (N.S. Beloborodova, I.V. Nalyvaichenko, A.I. Popov, I.F. Polyakova, L.Yu. Savinova and others); works describing the specifics of pedagogical means of forming value orientations (G.M. Kodzhaspirova, I.Ya. Lerner, A.M. Novikov, I.P. Podlasy, M.N. Skatkin, V.A. Slastenin). The research of V.I. Lutovinova, N.E. Shchurkova, M.Yu. Novitskaya [7, 8] is devoted to the problem of the formation of the value attitude of the younger schoolchild to the "small homeland" as a system of universal human values associated with the national and cultural characteristics of the place where the child lives, which will later contribute to the emotional attitude to the nature of the native land, to others, to the historical and cultural heritage of the country. L.Yu. Savinova [9] shows that in the mind of a junior schoolchild, the image of the Motherland is rather blurred. So, when forming the value attitude towards the Motherland, the child should rely on a clear range of ideas about the homeland: family, home, school, city, country. Yu.K. Babansky, P.V. Konanykhin, O.I. Pavelko, L.F. Spirin define the formation of the value attitude towards the Motherlandas one of the tasks of patriotic education. T.A. Pomerantseva [10] examines the development of a primary school student not only from the intellectual perspective, but also focuses on the upbringing of an interacting, responsible, moral personality who is aware of themselves in the socio-cultural and political environment. A.G. Galchenko [11] indicates that the formation of civic self-consciousness is of strategic importance for the successful future of the Russian state. The author draws attention to the peculiarities of the formation of value orientations in students, and sees one of the ways to implement this process in the development of mechanisms of internal motivation focused on universal human ideals. E.V. 
Gryaznova, I.A. Treushnikov, S.M. Maltsev, identify negative trends in the development of education in our country, which are associated with the spread of informatization, which affects the intellectual and moral potential of the country [12].

A research of Kluckhohn C. [13] considers the experience of forming value orientations on the examples of different cultures and countries (Germany, Morocco, China). Roccas S., Sagiv L., Schwartz S.H., \&Knaf A. [14] analyze the relationship of the student's personal qualities with basic values, including the attitude to the Motherland. Schwartz S.H [15] conducted a study of value orientations in 20 countries, highlighting the most important of them - the value attitude towards the Motherland.

This variety of approaches emphasizes the relevance of the topicof our research.

\subsection{The objective of the work}

This study is based on the analysis of foreign and Russian scientific and methodological literature, which considers ways of forming the value attitude towards the Motherland; generalization of the authors' experience in the use of diagnostic materials; analysis of their own scientific activities.

The purpose of this article is to study the value attitude towards the Motherlandin children of primary school age. The authors utilize the following diagnostic tools: tasks, criteria for evaluating tasks, statistic processing of the results for children of 8-9 years of age.

The authors selected an experimental group of second grade students in the amount of 158 people from schools in Nizhny Novgorod and Nizhny Novgorod region. At the ascertaining stage, the amount of knowledge about the Motherlandwas determined, the ability for volitional manifestations in a practical direction related to the value attitude towards the Motherland was identified. Thus, the authors assessed the formation of each component that makes up the value attitude. We considered the following as the main manifestations: attitude to the Motherland and devotion to it, knowledge of history and pride in the heroic past of the Motherland, adherence to the values and traditions of our people; high level of personal morality, knowledge and acceptance of universal values.

On the basis of theoretical analysis, the levels of formation of the value attitude towards the Motherland among students were determined (Table 1).

To analyze and identify the features of the formation of the value attitude towards the Motherland, we compiled a diagnostic complex. It included questionnaireswith 10 open and closed questions each. Such arrangement helped to exclude the appearance of random data. As a diagnostic material, we used the methodology "Unfinished sentence":"What is the Motherland", the questionnaire "Where does the Motherland begin", the test "Attractions of our Motherland".

The diagnostic technique "What is Motherland" included 10 unfinished sentences: on the definition of the concept of Motherland, "small homeland", on feelings experienced for the Motherland, knowledge of the capital, the flag of the country, continuation of sentences on the topic of what it means to love and defend the Motherland, of what the Motherland should be like.

The questionnaire contained a range of questions related to knowledge of the symbols of the country, cultural traditions, features of certain holidays, family values; issues aimed at realizing oneself as a citizen of the country. The test "Attractions of our Motherland" took into account the answers related to the concept of "sightseeing", knowledge of cities and rivers of Russia, famous people of the country and Nizhny Novgorod region, interesting places of the "small homeland". We paid special attention to the questions, the answers to which contained variability: if guests from overseas come to visit, what places in 
Nizhny Novgorod you would introduce them to first? If you come to an unfamiliar country, how you will get to know it?

Table 1. Levels of formation of the value attitude towards the Motherland in children of 8-9 years of age.

\begin{tabular}{|c|c|c|c|c|}
\hline \multirow[t]{2}{*}{ No } & \multirow[t]{2}{*}{ Main components } & \multicolumn{3}{|c|}{ Levels of formation of value attitude } \\
\hline & & High & Medium & Low \\
\hline 1 & $\begin{array}{l}\text { Awareness of the } \\
\text { concept } \\
\text { "Motherland" }\end{array}$ & $\begin{array}{l}\text { The student has a vast } \\
\text { amount of knowledge } \\
\text { about the homeland, } \\
\text { knows } \\
\text { components of the } \\
\text { concept } \\
\text { "Motherland", "small } \\
\text { homeland", easily } \\
\text { applies their } \\
\text { knowledge in } \\
\text { practice, has an idea } \\
\text { of the country as a } \\
\text { subject of the world } \\
\text { system. }\end{array}$ & $\begin{array}{l}\text { The student is } \\
\text { characterized by the } \\
\text { presence of the } \\
\text { necessary } \\
\text { knowledge about } \\
\text { the Motherland, the } \\
\text { place where they } \\
\text { were born. Able to } \\
\text { apply knowledge in } \\
\text { practice with the } \\
\text { help of an adult. }\end{array}$ & $\begin{array}{l}\text { The student has a } \\
\text { small amount of } \\
\text { knowledge about their } \\
\text { country, culture and } \\
\text { history, incomplete } \\
\text { ideas about the } \\
\text { components of the } \\
\text { concept } \\
\text { "Motherland". } \\
\text { Fragmentary } \\
\text { knowledge about the } \\
\text { Motherland makes it } \\
\text { impossible to apply } \\
\text { them in practice. }\end{array}$ \\
\hline 2 & $\begin{array}{l}\text { Awareness of moral } \\
\text { categories }\end{array}$ & $\begin{array}{l}\text { The student correctly } \\
\text { and fully determines } \\
\text { moral qualities, not } \\
\text { only reflecting } \\
\text { knowledge, but also } \\
\text { indicating } \\
\text { corresponding the } \\
\text { behavior, } \\
\text { demonstrates a high } \\
\text { level of personal } \\
\text { morality. Feels } \\
\text { pridein the heroic } \\
\text { pastof the country, } \\
\text { knowsitsheroes, } \\
\text { values and traditions } \\
\text { of its people. }\end{array}$ & $\begin{array}{l}\text { The student in the } \\
\text { definition of moral } \\
\text { categories } \\
\text { combines a positive } \\
\text { and negative } \\
\text { attitude towards } \\
\text { them, may hesitate } \\
\text { in choosing the } \\
\text { correct judgments. } \\
\text { Shows incomplete } \\
\text { knowledge of the } \\
\text { fateful landmarks } \\
\text { of the country, its } \\
\text { heroes, traditions. }\end{array}$ & $\begin{array}{l}\text { The student } \\
\text { demonstrates } \\
\text { negative attitude } \\
\text { towards moral } \\
\text { categories, is prone to } \\
\text { erroneous definitions } \\
\text { of the essence of } \\
\text { moral qualities. He } \\
\text { does not know the } \\
\text { traditions, the past of } \\
\text { the Motherland, is } \\
\text { indifferent to the } \\
\text { heroes and defenders } \\
\text { of the country, the } \\
\text { experience of their } \\
\text { ancestors. }\end{array}$ \\
\hline 3 & $\begin{array}{lr}\text { Activity aspect } \\
\text { (involvement in } \\
\text { social activities) }\end{array}$ & $\begin{array}{l}\text { The student is } \\
\text { characterized by } \\
\text { stable, independent } \\
\text { behavior in various } \\
\text { conditions } \\
\text { communication, of } \\
\text { demonstrates } \\
\text { combination a } \\
\text { independence of } \\
\text { actions from external } \\
\text { judgments and } \\
\text { expectations, } \\
\text { awareness } \\
\text { validity of the choice } \\
\text { of behavior. Actively } \\
\text { take spartin various } \\
\text { patriotic events. }\end{array}$ & $\begin{array}{l}\text { The student is } \\
\text { distinguished by the } \\
\text { situational nature of } \\
\text { decision-making, } \\
\text { partial commission } \\
\text { of ill-considered } \\
\text { actions, little } \\
\text { experience in } \\
\text { manifesting his } \\
\text { own attitude in } \\
\text { action. Takes part } \\
\text { in social and } \\
\text { patriotic events } \\
\text { under the guidance } \\
\text { and supervision of } \\
\text { a teacher }\end{array}$ & $\begin{array}{l}\text { The student } \\
\text { demonstrates an } \\
\text { unwillingness to } \\
\text { independently choose } \\
\text { the line of behavior, } \\
\text { an unstable position } \\
\text { when different } \\
\text { opinions clash. } \\
\text { Experiences difficulty } \\
\text { in formulating their } \\
\text { own point of view or } \\
\text { inability to prove it, } \\
\text { apathy in behavior. } \\
\text { Shies away from } \\
\text { participating invarious } \\
\text { activities. }\end{array}$ \\
\hline
\end{tabular}

Let's analyze the results of the completed diagnostic assignments. Fulfillment of the tasks of the first diagnostic technique "Unfinished sentence" provided for obtaining 
answers to a number of questions oriented towards the understanding of the concept of "Motherland". The answer to the question "What is Motherland? This ... "allowed building the following associative array: the place where you were born (45.6\%); Russia $(17.7 \%)$, my country $(13.9 \%)$; native land $(10.1 \%)$; a large and bright place $(6.3 \%)$; where people live $(3.8 \%)$; where I live $(2.5 \%)$. Second-graders understand what the Motherland is. $89.9 \%$ of the respondents relate this concept to the place where they live and were born. Continuation of the sentence "What is a "small homeland"? This... "caused certain difficulties for schoolchildren, some of the students did not cope with the task to continue the statement $(32.9 \%)$, defined their "small homeland" as a city or village where they live; the majority of schoolchildren (51.2\%) and a certain number of children $(15.7 \%)$ included in this concept "my home, my family". Almost all the students correctly indicated the capital of our Motherland (95\%), the rest of the children built a sentence as follows: "The capital of our Motherland is Russia" (5\%). 100\% of second graders continued statement about the colors of the national flag and the coat of arms correctly. The answers to the questions are presented in Table 2.

Table 2. Percentage ratio of second-graders' statements about the Motherland (understanding of the concept).

\begin{tabular}{|l|l|}
\hline Unfinished sentences & Answers of SecondGraders \\
\hline $\begin{array}{l}\text { What feelings do you have for the } \\
\text { Motherland? } \\
\text { I--- ------- my Motherland. }\end{array}$ & $\begin{array}{l}\text { love, take care, adore, respect } \\
\text { Motherland? It means... }\end{array}$ \\
\hline To defend your Motherland means... & $\begin{array}{l}\text { Take care, save, protect, not litter, fight for it, take care, } \\
\text { pity, respect, be proud, cherish, treat it like a mother, } \\
\text { thank it, praise it, appreciate it with all my heart, admire } \\
\text { it. }\end{array}$ \\
$\begin{array}{l}\text { To fight for it, to fight evil, to stand up for honor, not to } \\
\text { abandon in trouble, to fight against an enemy, to be brave, } \\
\text { to fulfill your duty, not to give offense. To take care of } \\
\text { people and nature, not to let it be destroyed, to preserve it } \\
\text { for posterity. }\end{array}$ \\
\hline $\begin{array}{l}\text { What your Motherland should be? My } \\
\text { Motherland should be... }\end{array}$ & $\begin{array}{l}\text { Kind and big, clean, rich, blooming, beautiful, growing, } \\
\text { happy, dear, attractive to people, beloved, beautiful, } \\
\text { healthy, smart. Reliable, strong, mighty, proud, brave, } \\
\text { courageous, strong, great, peaceful. Hot, fresh, lively, } \\
\text { light, bright, sunny, spacious, wide. }\end{array}$ \\
\hline
\end{tabular}

Thus, the analysis of the results - Awareness of the concept of "Motherland" showed that the majority of second graders $(51.8 \%)$ have the necessary knowledge about the Motherland, represent the components of this concept (45.5\%), name the capital and the flag of Russia (97.2\%), feel love and respect for the Motherland (100\%), understand what it means to defend the Motherland (80.3\%) and what the Motherland should be like (66.4\%).

Completing the tasks of the questionnaire included answers to the questions: who are Russians? Is it necessary to be Russian to be considered a Russian? Can a modern person be proud that he/she is a Russian? How to identify a Russian? Who are the real Russians? Who can be called a real Russian? What are the negative and positive qualities of Russians? Where would you like to live in the future? Are there people in your environment who you would like to take as an example?

The answer to the first question - who are the Russians? - revealed that second-graders most often refer to the definitions of "people who live in Russia" (53.1\%), "Russian citizen" (13.2\%), the rest of the respondents did not answer $(20.3 \%)$ or named themselves as an example ("this is me" $13.7 \%$ ). When answering the second question about the need to be Russian in order to be considered a Russian, the options of the group of respondents 
were approximately divided in half: $49.3 \%$ of students believe that it is important to be Russian, $50.7 \%$ answered in the negative. We assume that second-graders do not clearly understand the ethnicity of "Russian" and probably confused it with Russian citizenship. Such a confusion of concepts is typical of younger schoolchildren, who are focused not on exact lexical understanding, but on the pattern of using words in the speech of the media, adults. The data on the third question showed that all subjects were proud of their belonging to Russia. The answer to the question, how a Russian can be identified, testified to identification by language $(68.3 \%)$, by place of residence $(11.3)$, by character $(5 \%)$, given name $(3.7 \%)$, attitude to Russia (3.1\%), by skin and hair color $(1.8 \%)$, by shapka $(1.2 \%)$. The next question suggested that second-graders would list historical, contemporary personalities, perhaps literary or movie heroes or characters, who could be called real Russians. According to the results of statistic processing and ranking, it was determined that children find it difficult to choose such people: $22.1 \%$ of students could not give examples, $41.1 \%$ chose their parents, friends and themselves as examples; everyone who lives in Russia was attributed to real Russians by $15 \%$ of the subjects, $14.5 \%$ considered the president to be a real Russian, the rest of the children gave single answers, including epic, fairy-tale characters, cartoon characters, a teacher, and the president. The results obtained allow us to conclude that the children did not receive a deep understanding of the content of the concept of "real Russian". Positive and negative qualities of Russians mentioned in students' answers are presented in Table 3.

Table 3. Variants of answers to the question: "What are the negative and positive qualities of the Russians?".

\begin{tabular}{|l|l|l|l|}
\hline \multicolumn{2}{|l|}{ Positivetraits (Students' choice, \%) } & Negativetraits (Students' choice, \%) \\
\hline Kindness, sociability & 39,3 & Rudeness, laziness, pugnaciousness & 31 \\
\hline Humor & 34,8 & Poor knowledge of foreign languages & 20,8 \\
\hline Power & 15,8 & They often complain, have bad habits & 18,9 \\
\hline Hardwork, perseverance & 6,3 & $\begin{array}{l}\text { They do not take care of nature, throw } \\
\text { garbage }\end{array}$ & 15,8 \\
\hline Courage & 3,8 & Don't always tell the truth & 13,2 \\
\hline
\end{tabular}

Among the answers of the second-graders, there were opposite ones in meaning: they love their children - they do not love (scold) their children, generosity - greed, courage cowardice. Since the same student gave such controversial answers, we decided not to take them into account in statistic processing. We have to note that when completing this task, the students found it difficult to choose negative qualities, since they were guided by a close circle of people to whom the children have a positive attitude and do not see negative traits.

The answers to the question about the intended place of residence in the future made it possible to establish the following pattern: $89.2 \%$ of students want to stay in Russia, some of them choose large cities with developed infrastructure - Moscow, St. Petersburg, Kazan, Sochi, Krasnodar. Many of the second graders would like to live in the south of Russia. One student indicated that he would like to live in the past in Russia. An insignificant part of children (10.8\%) chose Turkey, England, France, Uruguay, America.

The data obtained for the test "Attractions of our Motherland" are reflected in Table 4.

After statistical processing and ranking of the answers, it was discovered that about a third of all the students find it difficult to complete many tasks.It allows us to conclude that students have little experience in dealing with such situations. 
Table 4. Results of the diagnostic method "Sights of Russia".

\begin{tabular}{|c|c|c|}
\hline Open-endedquestions & Students' answers & $\begin{array}{l}\text { Students' } \\
\text { choice, \% }\end{array}$ \\
\hline \multirow{5}{*}{$\begin{array}{l}\text { What is a place of } \\
\text { interest? }\end{array}$} & Something beautiful, the best place in the city & 20,2 \\
\hline & The place people are proud of & 17,1 \\
\hline & Different buildings & 13,3 \\
\hline & Achievements of the city & 12,1 \\
\hline & Don’t know & 37,3 \\
\hline \multirow{9}{*}{$\begin{array}{l}\text { What interesting places } \\
\text { are there in Russia? }\end{array}$} & Museums: local history, Hermitage, Mausoleum & 24 \\
\hline & The Kremlin, Red Square & 17,1 \\
\hline & Eternal Flame, Tsar Cannon, Tsar Bell & 14,6 \\
\hline & Architecture, different buildings & 9,5 \\
\hline & Parks, fountains, zoos & 6,3 \\
\hline & $\begin{array}{l}\text { The confluence of the Volga and Oka rivers, } \\
\text { Lake Baikal }\end{array}$ & 3,2 \\
\hline & Shoukhov Tower & 3,2 \\
\hline & MacDonald's & 1,9 \\
\hline & Don’t know & 20,2 \\
\hline \multirow{7}{*}{$\begin{array}{l}\text { If you come to a new city } \\
\text { how would you get to } \\
\text { know it? }\end{array}$} & Will buy a map and a guide & 24,3 \\
\hline & Will ask locals many questions & 18,3 \\
\hline & Juststroll the streets & 10,7 \\
\hline & Will try some local food & 6,9 \\
\hline & Will go sightseeing & 3,8 \\
\hline & Will buy a dictionary & 2,5 \\
\hline & Don'tknow & 33,5 \\
\hline \multirow{6}{*}{$\begin{array}{l}\text { If you have foreign } \\
\text { visitors what would you } \\
\text { show them? }\end{array}$} & Will take them on a city tour & 18,9 \\
\hline & Will tell them about my country and its people & 17,1 \\
\hline & Get them acquainted with local food & 12,1 \\
\hline & Get them acquainted with my family and friends & 9,6 \\
\hline & Teach them some Russian, some polite words & 8,8 \\
\hline & Don'tknow & 33,5 \\
\hline
\end{tabular}

We assessed the activity aspect of the formation of the value attitude towards the Motherland using the diagnostic technique of M.I. Shilova [16], where the main criteria were: participation in cultural, sports and patriotic events of the city, the activities of schoolchildren related to the city improvement (street, yard); participation in projects related to regional studies; caring for loved ones. The data obtained showed that a significant part of the students is at the middle (44.3\%) and low levels (36.7\%)of the formation. $19 \%$ of the schoolchildren displayed active, independent behavior, which reflects the position of a person who loves their homeland, their native land. The analysis of the results of the diagnostic method allows us to draw a conclusion about the difficulties second-graders experience when they are involvedin social activities, since, in our opinion, schoolchildren do not yet have sufficient skills to participate in social life.

The analysis of the results of the diagnostic work carried out made it possible to divide the students according to the formation levelof the value attitude towards the Motherland. 
Table 5. Distribution of children aged 8-9 according to the levels of value attitude towards the Motherland.

\begin{tabular}{|l|l|l|l|l|l|}
\hline \multicolumn{2}{|l|}{ High Level } & \multicolumn{2}{l|}{ Middle Level } & Low Level \\
\hline $\begin{array}{l}\text { Number of } \\
\text { Students }\end{array}$ & $\%$ & Number of Students & $\%$ & Number of Students & $\%$ \\
\hline 35 & 22,2 & 63 & 39,8 & 60 & 38 \\
\hline
\end{tabular}

Thus, the data of the ascertaining stage showed an average and low level of formation of the value attitude towards the Motherland of children of 8-9 years of age.

When drawing up a plan of formative activities, we took into account the peculiarities of age, the results of the ascertaining stage, the requirements of the Federal State General Education Standard of Primary General Education (FGOS NOO) [17]. The tasks of the experiment included the gradual implementation of a set of tasks, exercises, activities related to the formation of the value attitude towards the Motherland. Weidentified three levels of achievement. At the first level, junior schoolchildren acquire social knowledge and ideas about Russia as the Motherland, about their "small homeland", about the culture and traditions of the multinational population of Russia, about moral norms and behavioral culture. The second level of achievements is based on the experience of younger schoolchildren gaining a positive attitude towards the basic values of society (person, family, Motherland, culture, traditions), among which the most important are the formation of patriotism and civic consciousness, self-awareness as a patriot of their Motherland. The third level involves gaining experience of cultural behavior, experience of social care for loved ones and the surrounding reality, the formation of the value attitude in children towards the Motherland. We took into account that the formation of a value attitude towards the Motherland presupposes a temporal extension, therefore, we relied on certain stages: the stage of realizing a specific value orientation; acceptance stage; the stage of implementation in their own activities and behavior.

Within the framework of the formative stage, the following content lines were implemented: "Russia is my Motherland", "Native land", "I am a patriot of my country", "Father's house", "Culture and traditions of my people". Each content lineinvolved the use of forms and methods of work that allow younger students to be involved in the events actively, such as role-playing games, conversations and discussions, round tables, guessing and composing riddles about the Motherland and family, developing crosswords, different types of dramatization [18], exercises on the use of the rules of conduct, participation in the holidays. We paid special attention to working with literary and informational texts [19]. Such work allows you to enrich the inner world of a student, gets acquainted with patriots and famous people of the country, historical and cultural monuments.

The content line "Native Land" was based on the study of the peculiarities of the history and development of the "small homeland". Project technology was used. The study of the homeland enhances the child's sense of belonging, belonging to their homeland. It should be noted that the age characteristics of junior schoolchildren do not allow them to work on a project without any support and assistance of adults. The main task of a teacher is the socalled guiding participation, which contributes to the student'smastery of the skills of searching, collecting, processing and interpreting material. When implementing a project, we propose to focus on eight main stages [20]: Stage 1 - problem statement, definition of the project theme; Stage 2 - formulating the goal, objectives and hypotheses of the proposed research, drawing up a step-by-step plan; Stage 3 - review and analysis of the necessary material on the chosen topic, interaction with the older generation, visiting museums, participating in excursions and expeditions dedicated to the chosen topic; Stage 4 - analysis and processing of the collected material, its systematization and classification; Stage 5 conducting a survey of students in parallel classes, adults on the problem proposed; Stage 6 
- the practical part of the work (making models of costumes, national and family dishes, dialect dictionaries); Stage 7 - presentation of results in the form of presentations, charity events, holidays, newspaper design, etc. At the 8th stage, the experience gained is reflected, the main results of the project are summed up. We have implemented the following projects: "The past and the present of the streets of my native city", "In honor of whom the street where I live is named", "Architecture of my native city", "Sights of my native land", "Famous people of my "small homeland", "Forward to the future: what my land will be like in 100 years ", "Clean house (street, city)".

During the formative stage, second-graders showed significant changes in all indicators of the formation of the value attitudes towards the Motherland. The analysis of the results of the control stage showed the effectiveness of formative activities: 52 schoolchildren (37.6\%) showed a high level of formation of value attitudes towards the Motherland, 96 students $(60.7 \%)$ made up the average level, and 20 people $(12.7 \%)$ remained at the low level. The dynamics are most evident in the indicators "Awareness of the concept of "Motherland" and "Involvement in social activities".

\section{Conclusions}

The study made it possible to solve a number of research problems. For the first time, the value attitude towards the Motherland among the schoolchildren of 8-9 years old was purposefully diagnosed. The results were obtained empirically and reflect the peculiarities of understanding by younger schoolchildren of the concepts "Motherland", "small homeland", ideas about cultural values, social ideals, about themselves, their place in society. It allows to define a student as a person who recognizes their own identity and is included in social space of Russia. Difficulties in the formation of a value attitude towards the Motherland are determined/ They are associated with the choice of authoritative models, heroes, inclusion in active social activities. The model of the formative stage, which includes five content lines, contributed to the comprehension of the image of the Motherland and the citizen of Russia by students, formed a positive attitude towards basic values, and developed the student's readiness to be involved in active social activities.

The results of the formative stage made it possible to draw a conclusion about the effectiveness of formative activities in the organization of experimental work. Thus, the formation of the value attitude towards the Motherland in younger schoolchildren will contribute to the development of moral and personal qualities of the child, enrich social experience, and ultimately ensure the future of the country.

\section{References}

1. R.I. Salakhova. Actualization of the formation of a value attitude towards the Motherland among young people. Current problems of science and education, 1, 208214 (2013)

2. A.Ya. Danilyuk, A.M. Kondakov, V.A. Tishkov, The concept of spiritual and moral development and education of the personality of a citizen of Russia in the field of general education: project (Moscow: Prosvescheniye, 2009)

3. B.C. Mukhina. Developmental psychology: phenomenology of development, childhood, adolescence, p. 456 (Moscow, 2004)

4. V.A. Sukhomlinsky, I give my heart to children, p. 288. (Moscow, 2016)

5. K.D. Ushinsky, Selected Works of the Book. 3. Man as a subject of education: Experience of pedagogical anthropology, p. 557 (N. Novgorod, 2005) 
6. P.Ya. Halperin, Lectures on psychology, p. 397 (Moscow: Book House University, 2010)

7. V.I. Lutovinov. Military-patriotic education of Russian youth, p. 170 (Moscow, 2007)

8. M.Yu. Novitskaya, Monitoring of patriotic education in kindergarten and primary school, p. 154 (Moscow, 2010)

9. L.Yu. Savinova, Education of the subject position of a younger student in the system of value relationships to the world, Herzen's readings. Primary education, 4 (1), 91-96 (2013)

10. T.A. Pomerantseva, The main components of socialization and individualization of primary schoolchildren in a modern socio-cultural society, Vestnik of Minin University, 6 (3), 8-18, DOI: 10.26795 / 2307-1281-2018-6-3-8 (2018)

11. A.S. Galchenko, Features of the motivational structure of civic engagement in adolescents with different status of civic identity, Vestnik of Minin University, 7 (3), 8-26 (2019)

12. E.V. Gryaznova, I.A. Treushnikov, S.M. Maltseva, Alarming trends in the system of Russian education: analysis of the opinions of scientists and educators, Prospects for Science and Education, 2 (38), 47-57, doi: 10.32744 / pse.2019.2.4 (2019)

13. C. Kluckhohn, Values \& value-orientations in the theory of action: An exploration in definition and classification, In T. Parsons \& E. Shils (Eds.), Toward a general theory of action, 388-433. (Cambridge, MA: Havard University Press, 2001)

14. S. Roccas, L. Sagiv, S.H. Schwartz, A. Knafo, The big five personality factors and personal values, Personality and Social Psychology Bulletin, 28, 189-201 (2002)

15. S.H. Schwartz, Universals in the structure and content of values: Theoretical advances and empirical tests in 20 countries, In M.P. Zanna (Ed.) Fdvances in Experimental Social Psychology, 25, 1-65 (Orlando, Fl: Academic, 1992)

16. M.I. Shilova, To the teacher about the education of schoolchildren, p. 132 (1990)

17. Federal state educational standard of primary general education, p. 53 (Moscow, 2019).

18. O.V. Kolesova, S.K. Tivikova, O.A. Zimina, Dramatization as a means of forming functional reading literacy of primary schoolchildren, School technologies, 3, 71-77 (2019)

19. O.V. Kolesova, E.G. Gutsu, N.N. Demeneva, E.V. Kochetova, T.V. Mayasova, Research of reading literacy of younger students at the present stage of education development, Prospects for Science and Education, 2 (44), 240-254, doi: 10.32744 / pse.2020.2.19 (2020)

20. N.V. Ivanova, V.A. Kalyulina, E.V. Minaeva, Effective means and techniques for the formation of cognitive interest in younger schoolchildren, Prospects for Science and Education, 6 (30), 70-73 (2017) 